\title{
PYŁKI I ZARODNIKI - NIEDOCENIANE NARZĘDZIA KRYMINALISTYCZNE? MOŻLIWOŚCI PALINOLOGII KRYMINALISTYCZNEJ
}

\section{WPROWADZENIE}

Jak zauważył Stanisław Waltoś, postępowanie karne cały czas podlega dużym wpływom systematycznie rozwijającej się nauki oraz techniki. Rozwój nauk, które są w nim wykorzystywane, takie jak na przykład kryminalistyka czy medycyna sądowa, dostarcza procesowi karnemu nowych metod badawczych, dzięki którym możliwe jest zdobywanie nowych typów dowodów. Badania poligraficzne, identyfikacja na podstawie analizy DNA, podsłuchy elektroniczne czy identyfikacja na podstawie zapachu to jedne $z$ wielu nowych technik, jeszcze niedawno zupełnie nieznanych, a obecnie wręcz niezbędnych do zdobywania nowych dowodów ${ }^{1}$. Współczesna kryminalistyka to nauka, która wykorzystuje dokonania wielu dyscyplin naukowych, często przystosowując je do swoich potrzeb lub w oparciu o nie wypracowuje zupełnie nowe, własne techniki ${ }^{2}$. W kryminalistyce używa się nie tylko nauki związanej ze zwalczaniem przestępstw i innych nieprawidłowości społecznych, lecz także medycyny, psychologii sądowej, nauk przyrodniczych, społecznych i technicznych ${ }^{3}$.

S. Waltoś, P. Hofmański, Proces karny. Zarys systemu, Warszawa 2016, s. 346.

2 E. Gruza, M. Goc, J. Moszczý́ski, Kryminalistyka - czyli rzecz o metodach śledczych, Warszawa 2008, s. 19.

3 Ibidem, s. 13. 
Mając więc na względzie wykorzystanie w kryminalistyce nauk przyrodniczych, celem poniższego artykułu jest zaprezentowanie relatywnie młodej gałęzi botaniki, jaką jest palinologia kryminalistyczna, oraz głównych kwestii z nią związanych.

Początek współczesnej palinologii dali w latach 40. XX w. Harold. A. Hyde oraz David A. Williams. Naukowcy ci byli aeropalinologami skupiającymi się na badaniu pyłków - alergenów zawartych w powietrzu. Wychwytywali je, identyfikowali i tworzyli kalendarze pylenia ${ }^{4}$. Nazwa tej gałęzi botaniki pochodzi od greckich słów „palyno” - rozsiewać, posypywać oraz „logos” - słowo. Palinologia jest więc nauką badającą ziarna pyłku oraz zarodniki roślin. To ich analizowanie morfologiczne i identyfikowanie w momencie, gdy są poza rośliną macierzystą, oraz badanie szlaków ich przemieszczania się (aeropalinologia). Nauka ta może być również wykorzystywana $z$ sukcesem w kryminalistyce, gdy badanie pyłku i zarodników służy procesowi dowodowemu; nazywana jest wtedy palinologią kryminalistyczną lub sądową ${ }^{5}$. Do badań przydatne są nie tylko współczesne pyłki; w wielu przypadkach wykorzystuje się także obecność pyłków kopalnych, które w związku z procesem karnym są niezwykle użyteczne w uzgodnieniu, co się wydarzyło i gdzie to nastąpiło ${ }^{6}$.

Ziarna pyłku oraz zarodniki są aktualnie standardowo zabezpieczane i używane jako dowód przede wszystkim w Australii, Nowej Zelandii oraz Wielkiej Brytanii ${ }^{7}$. W Nowej Zelandii palinologia kryminalistyczna jest stosowana rutynowo od przeszło 25 lat. Analizy palinologiczne pomagają przede wszystkim w skazaniu oskarżonych; ich najważniejszym zastosowaniem jest dostarczanie dowodów oraz wskazówek w dochodzeniu. Dowód pyłkowy doprowadził w wielu sprawach

4 P.E.J. Wiltshire, Forensic Palynology - its value to criminal investigation, [w:] Criminal and Environmental Soil Forensics, red. K. Ritz, L. Dawson, D. Miller, Dordrecht 2009, s. 132.

5 A. Zachuta, Palinologia kryminalistyczna, «Prokuratura i Prawo»10/2004, s. 129.

6 D.C. Mildenhall, P.E.J. Wiltshire, V.M. Bryant, Forensic palynology: Why do it and how it works, «Forensic Science International» 163/2006, s. 163.

Ibidem. 
do przyznania się podejrzanego do popełnienia przestępstwa. W tym kontekście palinologia kryminalistyczna może podarować prawu prosty i niedrogi dowód w dochodzeniach $\mathrm{w}$ danych sprawach ${ }^{8}$.

\section{PALINOMORfy Jako NARZĘDZIA KRYMinalistyCZNe}

Ziarna pyłku to struktury niewidoczne dla oka, o wielkości 5-200 $\mu \mathrm{m}$, mające w swoim składzie męskie komórki rozrodcze niezbędne w procesie zapłodnienia9. Występują one u roślin nasiennych i łączą się z komórkami żeńskimi na słupkach kwiatowych tych roślin ${ }^{10}$.

Zarodniki zaś to struktury produkowane przez rośliny niższe (mszaki, paprotniki) oraz grzyby, które służą im do rozmnażania bezpłciowego. Zarodniki mają zwykle małe rozmiary i skromną budowę, często są więc niezauważalne, trudne do identyfikacji i przypisania do określonej jednostki taksonomicznej ${ }^{11}$. Ziarna pyłku oraz zarodniki są nazywane palinomorfami ${ }^{12}$.

Pyłek jest strukturą bardzo odporną na niekorzystne czynniki. Dzieje się tak ze względu na jego warstwę zewnętrzną (egzynę), którą stanowi nadzwyczaj trwała substancja nazywana sporopoleniną. Jest ona niezwykle odporna na działanie kwasów oraz wysokiej temperatury. Dlatego też pyłek można ujawnić i zabezpieczyć na przedmiotach oraz różnych powierzchniach, na które działają nawet bardzo niekorzystne czynniki ${ }^{13}$.

Palinomorfy identyfikowane są przez palinologów dzięki swoim kształtom, rozmiarom, ścianie zewnętrznej, strukturze, powierzchni,

8 L.A. Milne, V.M. Bryant, D.C. Mildenhall, Forensic Palynology, [w:] Forensic Botany: Principles and Applications to Criminal Casework, red. H. Miller Coyle, Boca Raton 2005, s. 222.

9 D. Bajerlein, M. Wojterska, Ł. Grewling, M. KoKociński, Botanika sądowastan wiedzy i możliwości zastosowania w praktyce śledczej, «Problemy Kryminalistyki» 289/2015, s. 21.

10 E. Nogacka, Palinologia kryminalistyczna-dlaczego ja stosować i jak?, «Problemy Kryminalistyki» 255/2007, s. 82.

11 Ibidem, s. 82-83.

12 D. Bajerlein, M. Wojterska, Ł. Grewling, M. Kokociński, op. cit., s. 21.

13 Ibidem, s. 22. 
typowi, liczbie oraz układowi otworów. Wyniki identyfikacji palinomorfów mogą być różne. W przypadku niektórych rodzin roślin jednostki taksonomiczne mogą być zidentyfikowane aż do gatunku danej rośliny (np. babka lancetowata), w przypadku innych jedynie do rodzaju (np. wierzba), a nawet jedynie do rodziny (np. trawy) ${ }^{14}$.

Już w czasach starożytnych sposoby odnalezienia sprawców danych przestępstw instynktownie bazowały na regule, która wieki później została nazwana zasadą wymiany Locarda. Zdefiniowano ją zaledwie ponad 100 lat temu - na przełomie XIX i XX w. Zasada ta mówi o tym, że każdy kontakt między dwoma ciałami zawsze pozostawia ślad, a więc sprawca przestępstwa pozostawia swój ślad na miejscu zdarzenia, a także zabiera $\mathrm{z}$ tego miejsca jakiś ślad ${ }^{15}$. Zastosowanie w kryminalistyce botaniki również opiera się na powyższej zasadzie. To pierwsze założenie. Ślad botaniczny pomaga więc powiązać sprawcę przestępstwa, miejsce dokonania czynu zabronionego i ofiarę tego czynu ${ }^{16}$. Pyłki i zarodniki osadzają się na wszystkim, z czym następuje ich kontakt. Mogą osadzać się na ciele człowieka na danym miejscu zdarzenia, ale może on je tam również sam pozostawić, w sytuacji gdy jest po prostu ich nośnikiem. Podczas procesu oddechowego człowiek wdycha je także do dróg oddechowych, dlatego są tam często znajdowane. Osadzają się również na włosach, gdzie pozostają dłużej niż na ciele, z którego są łatwo usuwane podczas mycia. Ujawniane są także na odzieży, butach, narzędziach, przedmiotach, nawet na częściach pojazdów, takich jak karoseria, opony, nadkola, obicia tapicerskie, pedały gazu, sprzęgła i hamulca, na dokumentach, obrazach i meblach ${ }^{17}$. Każda pora roku wyróżnia się odrębnym rodzajem pylenia, a zebrany i zabezpieczony zbiór pyłków umożliwia jej dosyć dokładne oznaczenie, choć nie jest możliwe zdefiniowanie konkretnego roku kalendarzowego. Największą rolę pełnią więc pyłki i ziarna roślin niskich, które pojawiają się rzadko,

14 P.E.J. Wiltshire, op. cit., s. 133.

15 M. Kowalczy , M. Dylewska, A. Jakubczak, Molekularne metody identyfikacji osobniczej, [w:] Kryminalistyka w ujęciu naukowym, red. B. ZdUneK, K. MACIĄG, Lublin 2016, s. 72.

16 D. Bajerlein, M. Wojterska, Ł. Grewling, M. Kokociński, op. cit., s. 21.

17 A. ZaChuta, op. cit., s. 133. 
są charakterystyczne dla danego rejonu i przemieszczane są na nieduże odległości (rośliny zielne, grzyby i pleśnie) ${ }^{18}$.

Drugie założenie, na którym opiera się wykorzystanie nauki botanicznej, dotyczy fitogeografii, a więc lokalizacji danych gatunków roślin na świecie. Każdy gatunek ma swoje wymagania co do rodzaju gleby, zakresu temperatury, wilgotności powietrza itp. Jedne gatunki roślin mogą występować szeroko, w różnych warunkach środowiskowych, inne zaś będą obecne jedynie w ograniczonych lokalizacjach, ze względu na specyficzne wymagania środowiskowe ${ }^{19}$. Należy więc zdawać sobie sprawę ze znaczenia tego faktu - na przykład ujawnienie na zwłokach śladów botanicznych roślin, które nie są specyficzne dla danego środowiska, może wskazywać na to, że zwłoki po prostu zostały przeniesione ${ }^{20}$.

Powodów, dla których ziarna pyłku i zarodniki są tak efektywnymi narzędziami kryminalistycznymi, należy też szukać w czterech poniższych, bardzo istotnych faktach. Po pierwsze, wiele typów roślin wytwarzających ziarna pyłku i zarodniki rozprasza ich ogromne ilości, uwalniając je do powietrza. Palinomorfy mogą być niesione wraz z powietrzem i opadać następnie na ziemię, tworząc na niej cienką powłokę, nazywaną „deszczem pyłkowym” (całkowita ilość pyłku zdeponowana w jakiejś określonej lokalizacji). W niektórych miejscach zjawisko to jest tak silnie wyrażone, że grunty oraz powierzchnie wodne mogą stać się żółte. Chociaż nie stanowi to precyzyjnego pomiaru otaczającej wegetacji, to w każdym regionie świata „deszcz pyłkowy” dostarcza cennej informacji na temat obecnej tam wegetacji i staje się „odciskiem pyłkowym", który pomaga w zidentyfikowaniu danego regionu ${ }^{21}$. Po drugie, pyłek i zarodniki są mikroskopijnej wielkości, są niewidzialne

18 A. Konduracka, Ziarno prawdy - czyli o zastosowaniu palinologii w kryminalistyce, [w:] Materiały z konferencji „III Dni Kryminalistyki Wydziału Prawa i Administracji Uniwersytetu Rzeszowskiego", red. M. ZELEK, Rzeszów 2009, s. 316.

19 D. Bajerlein, M. Wojterska, Ł. Grewling, M. Kokociński, op. cit., s. 21.

20 Ibidem.

21 V.M. Bryant, Pollen and Spore Evidence in Forensics, [w:] Wiley Encyclopedia of Forensics Science ${ }^{2}$, red. A. JAmieson, A.A. Moenssens, Chichester 2014, s. 1, materiał dostępny na stronie Wiley Online Library, https://doi.org/10.1002/9780470061589. fsa085.pub2 (dostęp: 30 czerwca 2018 r.). 
dla ludzkiego gołego oka. Mogą osiąść na każdego rodzaju powierzchni. Dlatego też palinomorfy występujące na danym obszarze, zwłaszcza na miejscu zdarzenia, mogą stać się dowodami, które łączą podejrzanego lub jakiś przedmiot $\mathrm{z}$ tym danym regionem lub miejscem zdarzenia ${ }^{22}$. Po trzecie, mimo że około pół miliona rożnych roślin wytwarza pyłki lub zarodniki, każdy gatunek produkuje palinomorfy, które mogą być zidentyfikowane jako pochodzące z rośliny rodzicielskiej. Często jednak się zdarza, że różnice między pyłkami i zarodnikami blisko spokrewnionych gatunków lub nawet rodzajów mogą być tak niewielkie, że dokładna identyfikacja może być możliwa tylko po bardzo wnikliwych badaniach, z użyciem skaningowego mikroskopu elektronowego (SEM) lub elektronowego mikroskopu transmisyjnego (TEM), lub obu. W większości przypadków badania takie są jednak zbyt drogie i zupełnie niepraktyczne, szczególnie w wypadku rodzajów roślin, które liczą w sobie setki gatunków (np. Clematis) ${ }^{23}$. Po czwarte, większość pyłków i zarodników jest bardzo odporna na zniszczenie lub rozpad. To oznacza, że dowód z palinomorfów $z$ danego regionu lub miejsca zdarzenia może pozostać nietknięty przez setki, tysiące, a nawet tysiące i miliony lat. Jeśli materiał z miejsca zdarzenia jest prawidłowo zabezpieczany i przechowywany, nawet po kilkudziesięciu latach możliwe jest pozyskanie osadzonego pyłku i zarodników oraz wykorzystanie ich jako dowodu. Istnieją oczywiście wyjątki, w których palinomorfy ulegają zniszczeniu bardzo szybko, na przykład na zaoranych polach lub obszarach, gdzie gleby podlegają częstemu procesowi nasycania wodą i wysuszania ${ }^{24}$.

Mając na uwadze powyższe cechy pyłków i zarodników oraz możliwość ich wykorzystania jako ślady kryminalistyczne, wskazać można na ich znaczące role w następujących kwestiach:

- wykazania związku między podejrzanym a miejscem zdarzenia;

- wykazania związku między podejrzanym a przedmiotem pozostawionym na miejscu zdarzenia;

\footnotetext{
22 Ibidem.

23 Ibidem, s. 2.

24 Ibidem.
} 
- wykazania związku między miejscem ujawnienia a miejscem zdarzenia;

- udowodnienia lub obalenia alibi;

- weryfikacji listy podejrzanych;

- wyznaczania dróg przemieszczania się przedmiotów, w tym na przykład narkotyków;

- dostarczenia informacji dotyczących otoczenia, z którego pochodzi dany przedmiot;

- dostarczenia informacji dotyczących geograficznego źródła danego przedmiotu;

- wspierania policji w dochodzeniu i jego kierunkach;

- lokalizowania podziemnych grobów oraz szczątków ludzkich;

- ustalania losu ofiary przed śmiercią;

- określania czasu znajdowania się szczątków ludzkich w danym miejscu ${ }^{25}$.

Można więc uznać, że ślady te spełniają funkcje: organizacyjną, dowodową, wersyjną, rekonstrukcyjną i weryfikacyjną. Funkcja organizacyjna wyraża się w tym, że ujawnienie śladu prowadzi do konieczności podjęcia dalszych czynności kryminalistycznych i procesowych, a więc porządkuje prace nad śladem. Funkcja dowodowa polega na tym, że ślad świadczy o jakimś fakcie, dowodzi go i uzasadnia. Funkcja wersyjna polega na tym, że początkowo może istnieć kilka wariantów przedstawienia danego zdarzenia. To właśnie ślady odgrywają główną rolę w tworzeniu wersji danego zdarzenia, z których ostatecznie tylko jedna wersja jest zgodna z rzeczywistym jego przebiegiem i staje się jego rekonstrukcją. W tym przejawia się również funkcja rekonstrukcyjna śladu. Dostarcza on informacji i umożliwia rekonstrukcję oraz przedstawienie zdarzenia zgodnie z tym, jak przebiegło w rzeczywistości. Funkcja weryfikacyjna zaś prowadzi do zbadania i potwierdzenia lub wykluczenia prawdziwości czegoś. Pozwala na zweryfikowanie informacji przekazanych przez osobowe źródła dowodowe, na ich podstawie dochodzi do korekt wariantów zdarzenia, rekonstrukcji i ewentualnego typowania sprawcy

25 D.C. Mildenhall, P.E.J. Wiltshire, V.M. Bryant, op. cit., s. 163. 
danego zdarzenia. Funkcja ta wiąże się ściśle z funkcjami wersyjną i rekonstrukcyjną śladów ${ }^{26}$.

Ciekawe badania przeprowadzono w Polsce w 2014 r. Miały one na celu określenie optymalnych miejsc na ciele lub ubraniu ofiary bądź sprawcy danego czynu zabronionego do pobierania materiału badawczego palinologicznego, pod kątem najsilniejszego osadzenia się ziaren pyłku. Badania te przeprowadzono w trzech seriach: w dniach 29 marca, 7 kwietnia oraz 15 sierpnia 2014 r. na terenie Lublina (Ogród Saski i Park Akademicki), a także w okolicach miejscowości Górki w województwie podkarpackim. W dwóch pierwszych seriach eksperymentom poddano dwie osoby, a w trzeciej serii jedną. Każda osoba spacerowała przez godzinę, a potem zabezpieczono materiał do badania z ubrań z rękawów, nogawek oraz obuwia i toreb. Pobrano także materiał badawczy z włosów, czół i policzków. Ogólnie przebadano 29 preparatów mikroskopowych ${ }^{27}$. Wyniki tych badań ukazały, że najlepiej pobierać taki materiał badawczy z obuwia oraz nogawek spodni. W materiale badawczym pobranym $z$ tych miejsc zabezpieczano najwięcej ziaren pyłku oraz fragmentów gleby. Najmniej materiału znajdowano na twarzy - policzkach i czole oraz włosach. Podczas tych badań nie stwierdzono również zależności między rodzajem materiału, z którego wykonano ubranie, a stopniem osadzania się ziaren pyłku ${ }^{28}$. Wyniki pozwoliły także na dokładne określenie pory roku. W pierwszej turze badania oznaczono ziarna pyłku olszy i topoli, które kwitną na początku wiosny, w drugiej turze zaś odnotowano duże ilości pyłku brzozy, której szczyt pylenia w Polsce następuje w kwietniu. Wysoka koncentracja ziaren pyłku brzozy świadczyła o późniejszym terminie pobierania próbek w drugiej turze badawczej niż w pierwszej. W trzeciej turze stwierdzono skład pyłków 11 rodzajów roślin, które charakterystyczne są dla lata. Znaleziono również niewielkie ilości ziarna pyłku różnych drzew, co

26 Kryminalistyka. Wybrane zagadnienia techniki, red. G. KęDzierska, W. KęDZIERSKi, Szczytno 2011, s. 36 i n.

27 A. MAzur, Wykorzystanie palinologii w kryminalistyce, [w:] Kryminalistyka w ujęciu naukowym, red. B. ZDUNEK, K. MACIĄG, Lublin 2016, s. 207.

28 Ibidem, s. 214. 
może świadczyć o tym, że miejsce spaceru osoby badanej znajdowało się obok terenu leśnego ${ }^{29}$.

O rozmieszczeniu pyłków decyduje jednak sposób kontaktu z roślinami. Człowiek przemieszczający się przez na przykład łan zboża lub kukurydzy zbierze więcej pyłku na ramionach niż na nogach. Osoba stojąca pod drzewem może zebrać najwięcej pyłku na głowie, nakryciu głowy i na ramionach. Osoba opierająca się o jakąś powierzchnię zbierze pyłek tylko po tej stronie odzieży, która ma styczność z tą powierzchnią. Klęczący na ziemi może mieć najwięcej pyłku w środkowej części spodni. Osoba idąca przez niskie rośliny zielne i krzewy zbierze pyłek na nogach, nogawkach i obuwiu ${ }^{30}$.

Należy podkreślić, że palinomorfy mają zdolność łatwego łączenia się z każdą powierzchnią, z którą mają kontakt. Może to być ciało człowieka, odzież, różne przedmioty. Człowiek może zebrać z miejsca zdarzenia obecne tam pyłki i zarodniki, jak również pozostawić na miejscu zdarzenia te, które przyniósł na sobie. Palinomorfy, które pierwotnie były obecne na miejscu zdarzenia, mając zdolność łatwego łączenia się z różnymi powierzchniami, na przykład podczas drogi na miejsce zdarzenia, walki czy ucieczki, będą na ubraniu zarówno sprawcy, jak i ofiary ${ }^{31}$. Ma to olbrzymie znaczenie w określaniu miejsca zdarzenia, budowaniu wersji zdarzenia, weryfikacji danej wersji zdarzenia, zdobywaniu dowodów, typowaniu sprawcy i łączeniu sprawcy z ofiarą.

Warto także pamiętać, aby nie ograniczać występowania śladów palinologicznych jedynie do środowisk na zewnątrz pomieszczeń. W Nowej Zelandii znane są sprawy wykrycia sprawców i połączenia ich z miejscem zdarzenia w pomieszczeniu, po tym jak przeanalizowano pyłki pochodzące $\mathrm{z}$ roślin doniczkowych, które się tam znajdowały ${ }^{32}$. Dlatego tak ważna jest wiedza osoby, która zbiera i zabezpiecza materiał badawczy botaniczny na miejscu zdarzenia.

Ibidem, s. 210 i n.

E. Nogacka, op. cit., s. 86.

A. ZaChuta, op. cit., s. 133-134.

Ibidem, s. 87. 


\section{TeChNiCZNE ASPEKTY ANALIZY PyŁKOWO-ZARODNIKOWEJ}

Do analizy pyłkowo-zarodnikowej należy pobierać materiał badawczy, które nie jest objętościowo obszerny. Jeśli pobierany jest z gruntu, to wystarczy $1 \mathrm{~cm}^{3}$ gleby, ponieważ do badań niezbędne jest minimum 300 ziaren pyłku lub zarodników, a w $1 \mathrm{~cm}^{3}$ znajduje się ich zwykle o wiele więcej ${ }^{33}$.

Przy pobieraniu materiału badawczego należy używać czystych narzędzi. Materiał jest wkładany do szczelnych, jałowych pojemników. Przed zbieraniem materiału $\mathrm{z}$ innej lokalizacji niezbędna jest wymiana rękawiczek ${ }^{34}$.

Aby zabezpieczyć materiał badawczy z powierzchni gładkich, niezbędne jest użycie odpowiedniej taśmy przylepnej; w zbieraniu materiału badawczego z innych powierzchni, na przykład z ubrań, włosów itp., używa się specjalnych grzebyków ${ }^{35}$.

Do rutynowego badania używa się jednej z technik mikroskopii świetlnej (TLM) z powiększeniem oryginalnego rozmiaru maksymalnie do tysiąca razy, tak by obraz stał się odpowiedni do badania. Gdy potrzebne są wyższe powiększenia, na przykład do oceny drobnych szczegółów powierzchni ziaren pyłków lub do odróżnienia między sobą pyłków różnych gatunków roślin, stosuje się skaningową mikroskopię elektronową $(\mathrm{SEM})^{36}$. Jednakże, jak twierdzi Patricia Wiltshire, SEM oraz inne wyrafinowane metody mikroskopowe (np. konfokalna mikroskopia elektronowa) mają niewielkie praktyczne zastosowanie w rutynowej pracy palinologa sądowego, właśnie ze względu na to, że SEM przedstawia obraz tylko zewnętrznej powierzchni ziarna pyłku lub zarodnika. W przypadku pyłków często to elementy tworzące zewnętrzną ścianę (egzynę) widoczne w przekroju są kluczowe dla dokładności identyfikacji. Te szczegóły są łatwiejsze do odróżnienia dzięki mikroskopii $\mathrm{w}$ jasnym polu i mikroskopii kontrastowo-fazowej. W materiale przeznaczonym dla sądu konieczne jest zidentyfikowanie i zliczenie setek

\footnotetext{
33 A. Zachuta, op. cit., s. 139.

34 E. NogACKA, op. cit., s. 85.

35 A. KondurACKA, op. cit., s. 319.

36 L.A. Milne, V.M. Bryant, D.C. Mildenhall, op. cit., s. 223.
} 
palinomorfów znalezionych w przygotowanym preparacie i chociaż jest to technicznie wykonalne przy użyciu SEM, doświadczony palinolog nie potrzebuje go do przeprowadzenia identyfikacji ${ }^{37}$.

\section{Zebranie, ZABEZPIECZANIE, PRZECHOWYWANIE I BADANIE ŚLADÓW BOTANICZNYCH}

Aby doszło do przeprowadzenia badania palinologicznego do celów sądowych, należy najpierw zebrać ślad botaniczny, prawidłowo go zabezpieczyć, zidentyfikować zebrany materiał badawczy i połączyć go $\mathrm{z}$ danym zdarzeniem ${ }^{38}$.

Podstawową częścią badania palinologicznego jest zebranie materiału badawczego kontrolnego oraz porównawczego i jego zabezpieczenie. Materiał kontrolny to próbki z powierzchni gleby, które zawierają pyłki i zarodniki, jak również kurz, włókna, sadza, minerały lub inne materiały, blisko lub bezpośrednio związane z miejscem zdarzenia ${ }^{39}$. Materiał kontrolny jest niezbędny do badania palinologicznego, ponieważ jego zawartość stanowi podstawową informację o oczekiwanym zbiorze pyłków i zarodników dla określonego obiektu lub śladu pyłkowego $\mathrm{z}$ danego miejsca zdarzenia lub bliskiego mu miejsca. Materiał porównawczy zaś jest zbierany z pojedynczych, konkretnych miejsc w miejscu zdarzenia oraz wokół niego. Ten rodzaj materiału odzwierciedla spektrum pyłków i zarodników dokładnych lokalizacji, można go później porównać z innymi dowodami mającymi związek ze zdarzeniem. $\mathrm{W}$ momencie otrzymania wyników badania materiałów kontrolnego i porównawczego, a zatem konkretnych danych dotyczących pyłku, można rozpocząć ich porównanie z pyłkiem zabezpieczonym od podejrzanego lub z materiałem, który ma związek z miejscem zdarzenia. Poszukiwane są oczywiście ich podobieństwa ${ }^{40}$. Im więcej materiału kontrolnego zbiera się i bada, tym więcej otrzymuje się informacji na

\footnotetext{
37 P.E.J. Wiltshire, op. cit., s. 135.

38 D. Bajerlein, M. Wojterska, Ł. Grewling, M. Kokociński, op. cit., s. 28.

39 V.M. BRyANT, op. cit., s. 8.

40 Ibidem, s. 9.
} 
temat miejsca zdarzenia. Spektrum pyłków w materiale kontrolnym może się nieznacznie różnić w zakresie typów i składu procentowego danych pyłków. Połączenie wszystkich uzyskanych spektrów w całość ukazuje potencjalny zasięg zmienności pyłków, którego można się spodziewać w rzeczywistości na miejscu zdarzenia. Te dane potwierdzają lub wykluczają połączenie pyłków zabezpieczonych z przedmiotów lub podejrzanych z miejscem zdarzenia ${ }^{41}$.

Przechowywanie materiału badawczego powinno odbywać się w szczelnych pojemnikach, które zabezpieczą go przed dostaniem się wszelkich zanieczyszczeń. Pojemniki muszą być prawidłowo oznaczone i umieszczone w miejscu o temperaturze około $0^{\circ} \mathrm{C}$. Taki sposób przechowywania chroni materiał badawczy przed niszczącym wpływem drobnoustrojów na pyłki zawarte w tym materiale ${ }^{42}$.

Powiązanie typów pyłków i ich względnej częstotliwości występowania w danym zbiorze może być unikalne dla danej lokalizacji, regionu, większego obszaru geograficznego, a nawet kraju. Te zbiory pyłków dostarczają „odcisku pyłkowego”, który jest charakterystyczny dla danej lokalizacji. Staje się on materiałem kontrolnym dla danej lokalizacji, z którym porównywane są inne materiały badawcze. Różne typy zbiorowisk roślinnych, takie jak lasy, tereny leśne i wrzosowiska oraz różne środowiska ekologiczne wytworzą zróżnicowane zbiory pyłków. Podobnie, zbiory pyłków ze środowisk utworzonych przez ludzi, takich jak plantacje sosnowe, pobocza dróg, miasta, przedmieścia, ogrody podmiejskie, pozwalają je odróżnić od siebie. Materiał dowodowy pobrany w szczególności z butów lub pojazdów, zawierają zazwyczaj pyłki z więcej niż jednej lokalizacji. Opierając się na wiedzy o spodziewanych zbiorach pyłków występujących w danych zbiorowiskach roślinnych i środowiskach, możliwe jest określenie historii podróży niektórych przedmiotów, a nawet odkrycie, że ciało zostało przeniesione w inne miejsce po dokonaniu przestępstwa ${ }^{43}$.

\footnotetext{
41 Ibidem.

42 Ibidem.

43 L.A. Milne, V.M. Bryant, D.C. Mildenhall, op. cit., s. 231.
} 
Najważniejsze przy zabezpieczaniu materiału badawczego palinologicznego i wykonania odpowiednich badań są skrupulatność i sumienność. Staranne przeprowadzenie oględzin, ich dokumentacja wraz z wykonaniem zdjęć samego miejsca zdarzenia, a także miejsc zabezpieczania materiału kontrolnego oraz skupisk roślinności, rzetelne zebranie i zabezpieczenie materiału dowodowego oraz porównawczego odgrywają tu kluczową rolę. Dlatego w państwach, w których badania palinologiczne są rutynowo wykonywane, za zabezpieczenie materiału odpowiada palinolog $\mathrm{z}$ doświadczeniem. Tylko taka osoba posiada wiedzę dotyczącą tego, co i jak powinno zostać zabezpieczone ${ }^{44}$. Najczęściej jednak materiał zabezpieczany jest przez technika kryminalistyki, który powierza dalej materiał do badania palinologowi. Jest to niestety punkt, w którym mogą nastąpić liczne nieprawidłowości, prowadzące do tego, że materiał ostatecznie nie nadaje się do badania ${ }^{45}$. Dlatego też technik kryminalistyki, który zbiera i zabezpiecza taki materiał, powinien przejść odpowiednie szkolenie w dziedzinie botaniki. Odpowiednie zabezpieczenie śladów palinologicznych nie tylko gra rolę w prawidłowym przeprowadzeniu dalszych badań, lecz także umożliwia jego przechowanie i użycie do badania po jakimś czasie od momentu zebrania. Ma to ogromne znaczenie ze względu na ciągły rozwój nauki i to, co obecnie nie jest użyteczne do badania, może stać się użyteczne jako dowód w przyszłości ${ }^{46}$.

Podstawa prawna oględzin zawarta jest w art. $207 \$ 1$ k.p.k., który mówi o tym, że „w razie potrzeby dokonuje się oględzin miejsca, osoby lub rzeczy ${ }^{\prime 37}$. Dzieje się tak w przypadku potrzeby ujawnienia jakiegokolwiek śladu kryminalistycznego na miejscu zdarzenia, który może być w związku z popełnionym czynem. Oględziny nie są jedynie obserwacją zjawisk fizycznych i ich utrwaleniem. Obejmują także ocenę obserwacji zmysłowych, interpretację sytuacji przyczynowo-skutkowych, określanie wersji przedmiotowych, a także ich weryfikację oraz ocenę zebranych

\footnotetext{
44 A. Konduracka, op. cit., s. 319.

45 Ibidem, s. 319 i n.

46 D. Bajerlein, M. Wojterska, Ł. Grewling, M. Kokociński, op. cit., s. 28.

47 T. Bednarek, Dowód osmologiczny. Aspekty kryminalistyczne i procesowe, Warszawa 2008, s. 57.
} 
dowodów ${ }^{48}$ Takie spojrzenie na oględziny powoduje ich odpowiednie zabezpieczanie oraz późniejsze skuteczne wykorzystanie ${ }^{49}$.

Po ujawnieniu i zabezpieczeniu śladów palinologicznych przez specjalistę do czynności technicznych (zgodnie z art. 205 k.p.k.) lub przez samego biegłego palinologa rozpoczyna się dalej etap obróbki chemicznej materiału badawczego. Pozwala to na eliminację z pobranego materiału tła środowiskowego, czyli pozostałości roślinnych, zwierzęcych, mineralnych, zanieczyszczeń oraz mikroorganizmów ${ }^{50}$.

Zniszczenie tła środowiskowego w trakcie badania palinologicznego udaremnia możliwość przeprowadzenia innych badań danego materiału, na przykład przez ekspertów innych specjalizacji. Dlatego też badanie palinologiczne powinno się wykonywać na samym końcu, po innych badaniach ${ }^{51}$.

Następną częścią badania jest identyfikacja pyłków do najniższego możliwego poziomu taksonomicznego (tj. rodziny, rodzaju, gatunku). Aby tego dokonać, palinolog porównuje otrzymany zbiór pyłków i zarodników z innymi typami w zbiorach referencyjnych pyłków. Zbiory te mogą być rysunkami i zdjęciami zawartymi w artykułach lub książkach. Ponadto powstaje obecnie coraz więcej stron internetowych, które zawierają zdjęcia typów pyłków i zarodników oraz klucze referencyjne dla niektórych grup roślin. Jeśli jest to konieczne, część materiału badawczego można zbadać za pomocą SEM ${ }^{52}$.

Analiza pyłkowo-zarodnikowa klasyfikowana jest jako metoda statystyczna, ponieważ polega głównie na oznaczaniu i liczeniu pyłków i zarodników w preparacie ${ }^{53}$. Po zebraniu, zabezpieczeniu, przeprowadzeniu stosownych analiz i dokonaniu interpretacji materiału palinologicznego, biegły musi przygotować ekspertyzę, w takiej formie, by organ procesowy dokonał oceny jej wartości dowodowej ${ }^{54}$.

\footnotetext{
48 Ibidem.

49 Ibidem.

50 A. Zachuta, op. cit., s. 139 i n.

51 A. Konduracka, op. cit., s. 320.

52 L.A. Milne, V.M. Bryant, D.C. Mildenhall, op. cit., s. 230.

53 A. ZaChUtA, op. cit., s. 140.

54 E. NogackA, op. cit., s. 87.
} 


\section{ANALIZA ZIAREN PYŁKU I ZARODNIKÓW JAKO DOWÓD}

Ponieważ pojęcie dowodu ma wiele znaczeń, na temat których w literaturze istnieje wiele rozważań, S. Waltoś zaproponował rozwiązanie w postaci nadania pojęciu „dowód” znaczenia, które występuje w praktyce, a jest nim „środek dowodowy” 55 . Według autora jest to najbardziej trafne określenie, ze względu na to, że już od dawna utożsamia się z pojęciem „dowód” na przykład zeznanie świadka, wyjaśnienie oskarżonego, cechy właściwe dla miejsca, rzeczy czy zwłok. Jako środek dowodowy, a więc dowód w ścisłym znaczeniu, uznawany jest nośnik informacji o danym fakcie, który podlega udowodnieniu. Są to zeznania, wyjaśnienia, cechy rzeczy, miejsca, zwłok, dokumentu, opinia biegłego; wszystkie one informują, tak jak to zostało zaznaczone w definicji, o faktach podlegających udowodnieniu ${ }^{56}$. Według S. Waltosia źródłem dowodu jest osoba lub rzecz, od której pochodzi dowód - środek dowodowy ${ }^{57}$. Przedmiotem dowodu jest fakt podlegający udowodnieniu. Należy podkreślić, że udowodnieniu podlega nie jedynie sam czyn, ale również inne fakty, które zaszły lub nie zaszły, a wskazują na przestępstwo. Wyróżniamy więc dwie grupy faktów: fakt główny i fakty dowodowe ${ }^{58}$. W tym kontekście analiza pyłkowo-zarodnikowa dostarcza informacji na temat miejsca lub rejonu, z którego pochodzą dane ziarna pyłku lub zarodniki. Dzięki niej można określić, czy dana osoba miała styczność z określonym miejscem, można ustalić rolę danej osoby w danym zdarzeniu oraz można dokonać typowania sprawców lub wykluczenia danych z kręgu osób podejrzanych. Analiza ta jest niedrogą i szybką do zrealizowania metodą naukową, która oparta jest na wykorzystaniu materiału, który jest bardzo trwały oraz nietrudny do pozyskania i zabezpieczenia, a dowód z niej wynikający - jako naukowy przybiera postać ekspertyzy biegłego ${ }^{59}$.

\footnotetext{
55 S. Waltoś, P. Hofmański, op. cit., s. 349.

56 Ibidem, s. 350.

57 Ibidem.

58 Ibidem, s. 351.

59 A. ZaChuta, op. cit., s. 141.
} 
Warto w tym miejscu się zastanowić, czego dowodzą ślady palinologiczne pobrane z miejsca zdarzenia, poddane badaniom. Z całą pewnością należy uznać, że nie są one dowodem na sprawstwo przestępstwa danej osoby ${ }^{60}$. Jak twierdził Tadeusz Hanausek: „[... ] pomiędzy śladem obecności na miejscu zdarzenia a śladem sprawstwa tego zdarzenia niejednokrotnie występują ogromne różnice. Innymi słowy: ślad czyjejś obecności na miejscu zdarzenia nie zawsze jest równoznaczny ze śladem sprawstwa"61.

Wynik ekspertyzy palinologicznej może potwierdzić przyjętą wersję lub ją podważyć. Może doprowadzić do potwierdzenia alibi lub do jego obalenia. Ślad palinologiczny może prowadzić zarówno od ofiary do sprawcy, jak i od sprawcy do ofiary. Warunkiem odniesienia sukcesu jest jednak prawidłowy sposób pobrania materiału badawczego, odpowiednie ich oznaczenie, właściwe przechowywanie oraz prawidłowe wykonanie badań, a także właściwa ocena ich rezultatów ${ }^{62}$.

\section{CZY ŚLAD PALINOLOGICZNY MOŻE BYĆ DOWODEM POSZLAKOWYM?}

Dowód poszlakowy może być pełnowartościowym dowodem winy oskarżonego, gdy łańcuch poszczególnych poszlak, które są rozumiane jako udowodnione fakty uboczne, wiedzie pośrednio za pomocą logicznego rozumowania do ustalenia jednej wersji zdarzenia, czyli faktu głównego, z którego okazywałoby się, że oskarżony popełnił zarzucany mu czyn. Przypisanie winy na podstawie poszlak może zajść jedynie wtedy, gdy stanowią zamknięty krąg, z którego wynika, że ta osoba, wokół której się on zamyka, żadna inna, popełniła zarzucane przestępstwo ${ }^{63}$. Dodatkowo, łańcuch poszlak musi być nierozerwalny, bez żadnych luk, nie może być tu miejsca na propagowanie innej wersji. Wszystkie dowody

60 Ibidem, s. 135.

61 T. Hanausek, Meandry osmologii, «Palestra» 42.1-2/1998, s. 43.

62 A. ZaChutA, op. cit., s. 135.

63 T. BednareK, Osmologia - wybrane problemy praktyczne, «Temidium» 86.3/2016, s. 67. 
poszlakowe muszą być wiarygodne; istnieje konieczność, by wszystkie poszlaki wyrażane przez te dowody były udowodnione. W łańcuchu nie może być słabych poszlak. Muszą one być udowodnione lub wyeliminowane ${ }^{64}$. Można przytoczyć tu orzeczenie Sądu Najwyższego z 4 czerwca 1983 r. (RW 420/83), w którym wyrażono, że w procesie, w którym opierano się na dowodach poszlakowych, trafność ustaleń następuje wtedy, gdy ustalenia te nie mogą być zakwestionowane przez jakąkolwiek inną możliwą wersję zdarzeń ${ }^{65}$.

Nierzadko można spotkać się z poglądem, że dowód poszlakowy jest uważany za gorszy, mało pewny, wskazujący jedynie jakieś prawdopodobieństwo, rzucający jedynie cień na oskarżonego, niezezwalający na definitywne stwierdzenie. Pogląd taki jest szczególnie popularny wśród laików. Jest to opinia błędna, a nawet szkodliwa, ponieważ prowadzi do zbytniego podkreślenia roli przyznania się do winy. Dowód bezpośredni nie musi być wcale bardziej pewny i wiarygodny. Poszlaki zaś mogą okazać się w interesie dla oskarżonego, potwierdzając na przykład jego alibi $^{66}$.

W świetle powyższych dywagacji należałoby przyjąć, że wyniki badania śladów palinologicznych, podobnie jak na przykład ślady osmologiczne, nie mogą być dowodami bezpośrednimi, które wskazują winę oskarżonego, a mogą stać się poszlaką, w związku z czym można je rozpatrywać jako część dowodu poszlakowego ${ }^{67}$.

W tym miejscu trzeba podkreślić, że opinia eksperta w przedmiocie badań palinologicznych, jak każdy dowód, podlega ocenie niezależnych i niezawisłych organów procesowych. Zgodnie z art. 7 k.p.k., według zasady swobodnej oceny dowodów „organy postępowania kształtują swe przekonanie na podstawie wszystkich przeprowadzonych dowodów, ocenianych swobodnie z uwzględnieniem zasad prawidłowego rozumowania oraz wskazań wiedzy i doświadczenia życiowego" ${ }^{68}$. Duży wkład

64 S. Waltoś, P. Hofmański, op. cit., s. 355 i n.

65 S. Pikulski, Procesowe i kryminalistyczne aspekty możliwości wykorzystania śladów zapachowych, «Studia Prawnoustrojowe» 1/2002, s. 84.

66 S. Waltoś, P. Hofmański, op. cit., s. 354.

67 T. Bednarek, Dowód osmologiczny..., s. 238.

68 S. Waltoś, P. Hofmański, op. cit., s. 258. 
w jej przestrzeganie miał Sąd Najwyższy, którego liczne orzeczenia ostrzegały sędziów przed nadawaniem określonym dowodom większej rangi lub niedopuszczaniem niektórych ze względu na to, że ich wiarygodność z założenia nie budziła zaufania ${ }^{69}$. W tym kontekście nie można umniejszać znaczenia dowodu $\mathrm{z}$ opinii biegłego w zakresie badania palinologicznego, na przykład ze względu na to, że metoda nie jest obecnie szeroko stosowana i rozpowszechniona. Bez wątpienia analiza pyłkowo-zarodnikowa spełnia określone warunki metod naukowych. Przy przeprowadzaniu oceny dowodów przydatne są także standardy wypracowane przez Sąd Najwyższy USA w sprawie Dauberta, które precyzują kryteria dotyczące dopuszczania dowodu naukowego ${ }^{70}$.

\section{Potencjalne Kierunki RoZWoju Palinologit SĄDOWEJ}

Już w 2004 r. podczas konferencji palinologicznej w Grenadzie, P. Wiltshire z University College w Londynie omówiła nową metodę badania próbek gleby, nazywaną QEMSCAN. Polega ona na uzyskaniu obrazu próbek gleby w skaningowym mikroskopie elektronowym, który jest następnie analizowany cyfrowo. Dzięki temu otrzymane dane mineralogiczne dotyczące badanej gleby są statystycznie rzetelne i powtarzalne. W połączeniu z wynikami analizy pyłków i zarodników oraz badaniem makroszczątków otrzymuje się cały i zupełny obraz danego miejsca, na przykład miejsca zdarzenia ${ }^{71}$. Palinologia i mineralogia są najważniejszymi elementami analizy gleby. Zaletą QEMSCAN jest również to, że dane otrzymuje się szybko i z większości próbek gleby ${ }^{72}$.

Alternatywą dla analizy pyłkowo-zarodnikowej jest możliwość identyfikacji taksonomicznej pyłku z jego tzw. podpisu genetycznego. Oznaczanie tzw. barkodów DNA pyłków może bardzo rozwinąć palinologię sądową poprzez zwiększenie jej dostępności dla wielu laboratoriów

69 Ibidem, s. 262.

70 A. Konduracka, op. cit., s. 321.

${ }^{71}$ J. MadejA, XI Międzynarodowy Kongres Palinologiczny (Hiszpania, Grenada, 4-9 lipca 2004), «Prokuratura i Prawo» 5/2005, s. 175.

72 D.C. Mildenhall, P.E.J. Wiltshire, V.M. Bryant, op. cit., s. 168. 
kryminalistycznych, które są wyposażone w narzędzia molekularne ${ }^{73}$. Barkody DNA to jego fragmenty wykazujące małą zmienność wewnątrzgatunkową (w obrębie gatunku), a także dużą zmienność międzygatunkową (między różnymi gatunkami) ${ }^{74}$. Mimo że ta metoda nie została jeszcze zastosowana w palinologii sądowej, ostatnie postępy w opracowaniu miejsc barkodowych DNA u roślin oraz usprawnienie technologii sekwencjonowania do przetwarzania próbek wielu gatunków wskazują na to, że narzędzia te niebawem mogą być gotowe do zastosowania tej metody badania ${ }^{75}$.

Niezbędne jednak są do tego następujące elementy:

- zestaw genetycznych markerów, które mogą być amplifikowane wśród roślin nasiennych (tych, które wytwarzają pyłek kwiatowy) i które mogą po sekwencjonowaniu niezawodnie rozróżniać wysoki odsetek gatunków;

- izolacja DNA i metoda sekwencjonowania odpowiednia dla kontekstu danego dochodzenia;

- baza danych zawierająca sekwencje DNA markerów genetycznych dla większości gatunków roślin nasiennych ${ }^{76}$.

Oznaczanie barkodów DNA może znacznie zwiększyć efektywność i dokładność identyfikacji pyłków, odblokowując tym samym dla kryminalistyki potencjał pyłku jako kluczowego znacznika geograficznego oraz czasowego. I chociaż wciąż niezbędne jest dopracowanie kilku kwestii technicznych, źródła zagraniczne informują, że metoda ta jest blisko wprowadzenia do rutynowej analizy w kryminalistyce ${ }^{77}$. Pozwoli ona przede wszystkim na powiązanie danego pyłku i zarodnika nie do danego gatunku, ale do danego osobnika macierzystego ${ }^{78}$.

73 K.L. Bell, K.S. Burgess, K.C. Окамотo, R. Aranda, B.J. Brosi, Review and future prospects for DNA barcoding methods in forensic palynology, «Forensic Science International: Genetics» 21/2016, s. 110.

74 D. Bajerlein, M. Wojterska, Ł. Grewling, M. Kokociński, op. cit., s. 27.

75 K.L. Bell, K.S. Burgess, K.C. Окамотo, R. Aranda, B.J. Brosi, op. cit., s. 110.

76 Ibidem, s. 111 i n.

77 Ibidem, s. 115.

78 A. ZaChuta, op. cit., s. 130. 
8. Sprawy sąDOWE Na ŚWIEcie, W KTÓRYCh WyKorzystano PALINOLOGIĘ SĄDOWĄ

Pierwszą sprawą, w której wykorzystano ekspertyzę palinologiczną, była sprawa kobiety, która została zamordowana w maju. Stało się to w Szwecji w 1959 r. Aby rozwiązać tę sprawę, należało znaleźć odpowiedź na pytanie, czy miejsce ujawnienia zwłok to miejsce zdarzenia, czy ciało zostało tam podrzucone. Badanie odzieży denatki dostarczyło informacji o niskiej zawartości pyłków roślin rosnących w tym miejscu, ale ważną informacją było również to, że maj to pora będąca przed okresem pylenia roślin typowych dla tego rejonu. Wywnioskowano więc, że zwłoki musiały pozostawać cały czas w tym samym miejscu - na miejscu zdarzenia. Pozwoliło to na odnalezienie sprawcy tej zbrodni ${ }^{79}$.

W Nowej Zelandii opisywano sprawę napadu rabunkowego na sklep. Sprawca uciekł z miejsca zdarzenia motocyklem. Goniony przez policję porzucił motocykl i wbiegł na błotniste wzgórze, a potem skrył się w leśnym terenie. Następnego dnia na policję zgłosił się mężczyzna, który rozpoznał swój motocykl i poinformował policję, że został mu on wcześniej skradziony. Policja jednak nabrała podejrzeń co do domniemanego właściciela motocykla. Zadecydowano o przeszukaniu jego domu, w którym znaleziono parę butów ubrudzonych błotem. Zapytany o to, skąd na butach znalazło się błoto, mężczyzna odpowiedział, że z farmy, na której pracuje. Jednocześnie zaprzeczył temu, że był w okolicy porzucenia motocykla. Palinolog pobrał materiał kontrolny gleby z okolic farmy, na której mężczyzna miał pracować wcześniej, tak aby uzyskać „odcisk pyłkowy” tego miejsca. To samo zrobiono w miejscu porzucenia pojazdu. Na końcu zbadano pyłek znaleziony i zabezpieczony z błota na butach mężczyzny. Porównano otrzymane zbiory pyłków i określono, że pyłki zebrane z błota na butach odpowiadają zbiorowi pyłków miejsca porzucenia motocykla, a nie odpowiadają zbiorowi $\mathrm{z}$ farmy, na której mężczyzna pracował ${ }^{80}$.

79 Ibidem, s. 136.

80 V.M. Bryant, op. cit., s. 10. 
Za pomocą badania palinologicznego określono także pochodzenie i drogę przesyłki 500 gramów kokainy, którą przechwycono w Nowym Jorku. W pobranym materiale badawczym oznaczono trzy różne grupy pyłków. Jedna z nich reprezentowała rośliny rosnące w Boliwii i Kolumbii i odpowiadała miejscu pochodzenia koki, druga grupa pochodziła z kilku regionów Ameryki Północnej i odpowiadała miejscu cięcia i pakowania, a trzecia odpowiadała okolicom Nowego Jorku i informowała o tym, że tutaj ponownie cięto, pakowano i rozprowadzano kokainę $e^{81}$.

Palinologia pomogła również rozwiązać sprawę małżeństwa z Australii, któremu po wygranej na loterii dużej sumy pieniędzy porwano kilkuletniego syna. Ciało dziecka owinięte w pled znaleziono dość szybko i stwierdzono, że chłopiec został uduszony niedługo po uprowadzeniu. Na materiale pledu ujawniono ślady czerwonej zaprawy murarskiej oraz pyłek cyprysów, uprawianych w przydomowych ogrodach. Rozpoczęto poszukiwania pasującego do opisu domu, wokół którego miały rosnąć określone gatunki cyprysów, i w ich wyniku znaleziono odpowiedni dom. Po przedstawieniu sprawcy wyników badania palinologicznego, przyznał się on do popełnienia tej zbrodni ${ }^{82}$.

Dowód pyłkowy może być również użyteczny w ustaleniu przebiegu wydarzeń historycznych. W 1994 r. w Magdeburgu w Niemczech odkryto masowy grób, w którym znaleziono szczątki 32 młodych mężczyzn. Zostali oni zastrzeleni w egzekucji, ale nie wiadomo było, kto dopuścił się tej zbrodni. Istniały dwie możliwości, albo byli to partyzanci złapani i rozstrzelani przez Gestapo późną zimą lub wczesną wiosną 1945 r., albo rosyjscy żołnierze, zastrzeleni przez sowiecką tajną policję za odmowę wykonania rozkazu zabijania lokalnej ludności cywilnej podczas zamieszek przeciwko rządom Sowietów na tych terenach w roku 1953. W jamach nosowych 21 ciał znaleziono ziarna pyłków, które zbadano. Analiza pyłkowa wykazała dużą liczbę pyłków roślin, które pylą późnym latem, a nie roślin pylących wczesną wiosną. Porównano również pyłek ujawniony w materiale badawczym z gleby w miejscu pochówku ciał i potwierdzono, że pyłek znaleziony w jamach nosowych musiał zostać

81 L.A. Milne, V.M. Bryant, D.C. Mildenhall, op. cit., s. 239.

82 A. Zachuta, op. cit., s. 136. 
zainhalowany tuż przed śmiercią tych ludzi. Badania potwierdziły, że ofiary musiały zginąć w późnym czerwcu lub lipcu, a nie wiosną. Dlatego prawdopodobnie zostały zastrzelone przez sowiecką tajną policję późnym latem roku $1953^{83}$.

Palinologia odegrała również kluczową rolę, gdy w latach 1997-2002 Międzynarodowy Trybunał Karny dla byłej Jugosławii podjął się ekshumacji zbiorowych grobów w północno-wschodniej Bośni w ramach dochodzeń w sprawie zbrodni wojennych. Działanie to dotyczyło siedmiu masowych grobów (miejsc pierwotnych) wykopanych w Srebrenicy w lipcu 1995 r. do pochówku ciał zabitych cywilów. Aby zatrzeć ślady zbrodni, groby te zostały potajemnie i w pośpiechu ekshumowane trzy miesiące później, a większość ciał lub ich części przetransportowano i ponownie pochowano w innych lokalizacjach (miejscach wtórnych). Badania pyłków, gleby i osadów miały na celu uzyskanie profilu środowiskowego, który występował w miejscach pierwotnych, oraz dopasowanie przeniesionych ciał do pierwotnych lokalizacji ich pochówku. Zbadano ponad 24 stanowiska, zebrano i przeanalizowano ponad 240 próbek. Badania pyłków i osadów zostały połączone z badaniami mineralogicznymi w pierwotnych i wtórnych miejscach, sprawdzono, czy są między nimi połączenia ${ }^{84}$. Dane porównano również z odpowiednimi dowodami z badań balistycznych i odzieży. Otrzymano rzetelne dowody na to, że ciała zostały ekshumowane z miejsc pierwotnych, gdzie pyłki, roślinność i gleba były wystarczająco zmienne, aby możliwe było ich odróżnienie od miejsc wtórnych pochówków. Dowody wykorzystano w procesie sądowym zbrodni wojennych. Ogromne znaczenie miały tu niezmienne właściwości pyłków, zarodników i mineralogii ${ }^{85}$.

A naliza pyłkowo-zarodnikowa służy również badaniom zabytków i ich wiarygodności. Metoda ta posłużyła między innymi w badaniu Całunu Turyńskiego, relikwii, o autentyczność której naukowcy spierają się od wielu lat. W 1988 r. opublikowano wyniki datowania Całunu izotopem węgla C14. Badacze stwierdzili, że relikwia jest falsyfikatem,

83 V.M. BRYANT, op. cit., s. 13.

84 A.G. Brown, The use of forensic botany and geology in war crimes investigations in NE Bosnia, «Forensic Science International» 163/2006, s. 204.

85 Ibidem, s. 210. 
stworzonym w średniowieczu. Jednakże w 1973 r. botanik Max Frein pobrał z różnych miejsc Całunu 12 próbek w celu zbadania pyłków na nim zawartych. Oprócz tego naukowiec podczas swoich siedmiu podróży na Bliski Wschód zebrał zbiór pyłków, charakterystycznych dla tamtych terenów. Materiał porównawczy zabezpieczał z ziemi, ale również z mułu Jeziora Genezaret. Naukowiec zaprezentował wyniki swoich badań w trzech częściach. Zidentyfikował on początkowo 49 gatunków roślin oraz określił możliwą drogę relikwii do Europy, która wiodła z Palestyny, przez Mezopotamię, Konstantynopol, kończąc podróż we Francji. Po pobraniu dodatkowych próbek liczba oznaczonych gatunków roślin wzrosła do 57, a później do 76. Rezultaty analiz ugruntowały pogląd Freina o tym, że Całun Turyński jest autentyczny. Doszedł on do wniosku, że przypadkowe znalezienie się pyłku pochodzącego z Palestyny na Całunie, który byłby wykonany w czasach średniowiecza, jest bardzo mało prawdopodobne. Szczególnie, że znalazł się na nim również materiał kopalny. Dodatkowo, osiadanie pyłku na Całunie musiałoby być równoczesne $\mathrm{z}$ wielokrotną publiczną prezentacją tej relikwii. Bez względu na niemożność rozwiązania sporu dotyczącego autentyczności Całunu Turyńskiego, jest to bardzo interesujący sposób wykorzystania palinologii do badań zabytków ${ }^{86}$.

\section{Podsumowanie}

Palinologia to nauka skupiająca się na badaniu pyłków i zarodników. Mimo że palinologia sądowa jest stosunkowo młodą dziedziną, niezaprzeczalny jest jej ogromny potencjał dla kryminalistyki. Bez wątpliwości analiza pyłkowo-zarodnikowa jest metodą naukową, możliwą do zastosowania w polskim postępowaniu karnym jako ekspertyza biegłego ${ }^{87}$. Pyłki i zarodniki są tworami bardzo trwałymi i odpornymi, a równocześnie nietrudnymi do zebrania i zabezpieczenia ${ }^{88}$. Dlatego

\footnotetext{
A. Mazur, op. cit., s. 206.

A. ZaChuta, op. cit., s. 141-142.

88

Ibidem, s. 141.
} 
tė̇ są bardzo dobrym materiałem do analizy kryminalistycznej - na przykład identyfikacji miejsca popełnienia przestępstwa, rozróżnienia miejsca ujawnienia zwłok od miejsca dokonania czynu, czasu jego popełnienia oraz typowania sprawcy ${ }^{89}$. Niestety, wiedza na temat palinomorfów i ich możliwości jest wciąż mało rozpowszechniona, osoby biorące udział w procesach śledczych wykazują się wciąż dość dużą nieświadomością istnienia tego typu śladów kryminalistycznych ${ }^{90}$. Metoda ta wciąż nie jest powszechnie stosowana w większości państw. Również w Polsce jest ona metodą ogromnie niedocenioną. W Instytucie Botaniki Uniwersytetu Jagiellońskiego w latach 2016-2018 (informacja z 26 września 2018 r.) nie przeprowadzono ekspertyzy palinologicznej. Należy mieć nadzieję, że w przyszłości potencjał palinologii zostanie jednak odkryty i doceniony. Szczególnie w kontekście rozwoju technik barkodowania DNA i możliwości identyfikacyjnych związanych z tym faktem.

Złożony charakter palinologii sądowej wymaga również posiadania odpowiedniego wykształcenia osób zajmujących się badaniami palinologicznymi, które warunkuje uzyskanie jak największej liczby informacji $\mathrm{z}$ analizy środowiska. Dlatego wciąż brakuje odpowiedniej liczby ekspertów w tej dziedzinie, nawet w Wielkiej Brytanii czy Nowej Zelandii, a więc w państwach, w których analiza pyłkowo-zarodnikowa jest już uznaną metodą badawczą ${ }^{91}$.

Należy również podkreślić fakt, że badanie palinologiczne jest najbardziej efektywne w połączeniu z innymi metodami badawczymi. Tam, gdzie jest to możliwe, nie należy stosować palinologii kryminalistycznej w izolacji od innych nauk, a podejście interdyscyplinarne zawsze należy podejmować z wykorzystaniem pełnego zakresu analiz botanicznych, zoologicznych i nieorganicznych. Oznacza to, że najkorzystniej jest przeprowadzić pełną analizę środowiskową miejsc popełnienia przestępstw, przedmiotów oraz osób związanych z tymi miejscami. Badania takie nie powinny ograniczać się jedynie do kwestii botaniki czy nauk

\footnotetext{
89 D. Bajerlein, M. Wojterska, Ł. Grewling, M. Kokociński, op. cit., s. 28.

90 Ibidem, s. 29.

91 E. Nogacka, Palinologia kryminalistyczna..., s. 82.
} 
o Ziemi ${ }^{92}$. O tym, że jest to najkorzystniejsze rozwiązanie, świadczy wiele rozwiązanych spraw w historii światowej kryminalistyki.

\section{PYŁKI I ZARODNIKI - NIEDOCENIANE NARZĘDZIA KRYMINALISTYCZNE? MOŻLIWOŚCI PALINOLOGII KRYMINALISTYCZNEJ}

\section{Streszczenie}

W artykule przedstawiono najważniejsze kwestie dotyczące palinologii kryminalistycznej. Omówiono możliwości wykorzystania pyłków i zarodników jako ślady kryminalistyczne. Opisano ich cechy charakterystyczne, które sprawiają, że są one doskonałymi, choć niedocenianymi narzędziami kryminalistycznymi. Przedstawiono również metodykę badania palinologicznego. W dalszej części opracowania autorka skupiła się na analizie palinomorfów w roli dowodu. W artykule rozstrzygnięto także kwestię, jakim dowodem jest wynik badania palinologicznego. Przedstawiono kierunki rozwoju palinologii kryminalistycznej oraz opisano sprawy sądowe, w których dowód pyłkowy odegrał główną rolę.

\section{Pollen and Plant Spores: Underrated Forensic Tools? The Potential Offered by Forensic Palynology}

\section{Summary}

The article presents the most important issues in forensic palynology, discusses the potential offered by traces of pollen and spores as forensic evidence, and describes the characteristic features which make them perfect but underrated forensic instruments. I present the methods used in palynology and move on to consider the value of palynomorphs as evidence. I also address the question what kind of evidence is provided by the results of a palynological examination. I give an account of the

92 D.C. Mildenhall, P.E.J. Wiltshire, V.M. Bryant, Forensic palynology: Why do it..., s. 170 . 
development trends in forensic palynology and court cases in which pollen evidence played a major part.

Słowa kluczowe: palinomorfy; analiza; ślad botaniczny; identyfikacja, dowód.

Keywords: palynomorphs; analysis; botanical traces; identification, evidence.

\section{Literatura}

Bajerlein D., Wojterska M., Grewling Ł., Kokociński M., Botanika sadowa - stan wiedzy i możliwości zastosowania w praktyce śledczej, «Problemy Kryminalistyki» 289/2015, s. 20-32.

Bednarex T., Dowód osmologiczny. Aspekty kryminalistyczne i procesowe, Warszawa 2008.

Bednarek T., Osmologia - wybrane problemy praktyczne, «Temidium» 86.3/2016, s. 63-68.

Bell K.L., Burgess K.S., Okamoto K.C., Aranda R., Brosi B.J., Review and future prospects for DNA barcoding methods in forensic palynology, «Forensic Science International: Genetics» 21/2016, s. 110-116.

Brown A.G., The use of forensic botany and geology in war crimes investigations in NE Bosnia, «Forensic Science International» 163/2006, s. 204-210.

Bryant V.M., Pollen and Spore Evidence in Forensics, [w:] Wiley Encyclopedia of Forensics Science (2nd edition), red. A. Jamieson, A.A. Moenssens, Chichester 2014; materiał dostępny na stronie Wiley Online Library, https://doi. org/10.1002/9780470061589.fsa085.pub2, s. 1-15 (dostęp: 30 czerwca 2018 r.).

Gruza E., Goc M., Moszczyński J., Kryminalistyka - czyli rzecz o metodach śledczych, Warszawa 2008.

HanauseK T., Meandry osmologii, «Palestra» 42.1-2/1998, s. 41-46.

KęDZIERSKa G., KęDZIERSKi W. (red.), Kryminalistyka. Wybrane zagadnienia techniki, Szczytno 2011.

KondURACKa A., Ziarno prawdy - czyli o zastosowaniu palinologii w kryminalistyce, [w:] Materiały z konferencji „III Dni Kryminalistyki Wydziału Prawa i Administracji Uniwersytetu Rzeszowskiego", red. M. ZeLEK, Rzeszów 2009. Kowalczy K M., Dylewska M., Ja kubczak A., Molekularne metody identyfikacji osobniczej, [w:] Kryminalistyka w ujęciu naukowym, red. B. ZDUNEK, K. MACIĄG, Lublin 2016. 
Madeja J., XI Międzynarodowy Kongres Palinologiczny (Hiszpania, Grenada, 4-9 lipca 2004), «Prokuratura i Prawo» 5/2005, s. 173-176.

Mazur A., Wykorzystanie palinologii w kryminalistyce, [w:] Kryminalistyka w ujęciu naukowym, red. B. ZdUneK, K. MACIĄG, Lublin 2016.

Mildenhall D.C., Wiltshire P.E.J., Bryant V.M., Forensic palynology: Why do it and how it works, «Forensic Science International» 163/2006, s. 163-172.

Milne L.A., Bryant V.M., Mildenhall D.C., Forensic Palynology, [w:] Forensic Botany: Principles and Applications to Criminal Casework, H. Miller Coyle, Boca Raton 2005.

Nogacka E., Palinologia kryminalistyczna - dlaczego ja stosować i jak?, «Problemy Kryminalistyki» 255/2007, s. 82-89.

PikUlski S., Procesowe i kryminalistyczne aspekty możliwości wykorzystania śladów zapachowych, «Studia Prawnoustrojowe» 1/2002, s. 63-93.

Waltoś S., Hofmański P., Proces karny. Zarys systemu, Warszawa 2016.

Wiltshire P.E.J., Forensic Palynology - its value to criminal investigation, [w:] Criminal and Environmental Soil Forensics, red. K. Ritz, Dordrecht 2009.

Zachuta A., Palinologia kryminalistyczna, «Prokuratura i Prawo» 10/2004, s. $129-144$. 